\title{
Erratum
}

\section{Trade Reform and Institution Building: Peru and Argentina under the WTO}

ELÍAS A. BARACAT, J. MICHAEL FINGER, RAÚL LEÓN THORNE AND JULIO J. NOGUÉS

Volume 14, issue 4, pp. 579-615

The heading for Table 3 on p. 595 should have read "Table 3. Argentina: Import Substitution Policy Timeline".

We apologise for the error. 